\title{
Different Responses of Evapotranspiration Rates of Urban Lawn and Tree to Meteorological Factors and Soil Water in Hot Summer in a Subtropical Megacity
}

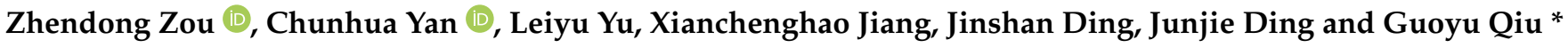 \\ School of Environment and Energy, Peking University Shenzhen Graduate School, Shenzhen 518055, China; \\ zouzd@pku.edu.cn (Z.Z.); dyanchen@pku.edu.cn (C.Y.); yuly@pku.edu.cn (L.Y.); 1901213199@pku.edu.cn (X.J.); \\ 2001212898@pku.edu.cn (J.D.); johnding@pku.edu.cn (J.D.) \\ * Correspondence: qiugy@pkusz.edu.cn; Tel.: +86-755-2603-3309
}

check for updates

Citation: Zou, Z.; Yan, C.; Yu, L.; Jiang, X.; Ding, J.; Ding, J.; Qiu, G. Different Responses of

Evapotranspiration Rates of Urban Lawn and Tree to Meteorological Factors and Soil Water in Hot Summer in a Subtropical Megacity. Forests 2021, 12, 1463. https:// doi.org/10.3390/f12111463

Academic Editor: Christopher Gough

Received: 7 October 2021

Accepted: 25 October 2021

Published: 27 October 2021

Publisher's Note: MDPI stays neutral with regard to jurisdictional claims in published maps and institutional affiliations.

Copyright: (c) 2021 by the authors. Licensee MDPI, Basel, Switzerland. This article is an open access article distributed under the terms and conditions of the Creative Commons Attribution (CC BY) license (https:/ / creativecommons.org/licenses/by/ $4.0 /)$.
Abstract: Urban evapotranspiration (ET) is an effective way to mitigate ecological challenges resulting from rapid urbanization. However, the characteristics of urban vegetation ET, especially how they respond to meteorological factors and soil water, remains unclear, which is crucial for urban ET regulation. Therefore, this study measured the actual ET rate of an urban lawn $\left(\mathrm{ET}_{\text {lawn }}\right)$ using the Bowen ratio system and an urban tree $\left(\mathrm{T}_{\text {tree }}\right)$ by a sap flow system in the hot summer of a subtropical megacity, Shenzhen. The results showed that the daily $\mathrm{ET}_{\text {lawn }}$ was more restricted by energy $\left(\mathrm{R}_{\mathrm{S}}\right)$ and diffusion conditions (vapor pressure deficit, VPD), while the daily $\mathrm{T}_{\text {tree }}$ was more restricted by VPD and relative extractable water (REW) in the urban area. The daily $\mathrm{T}_{\text {tree }}$ decreased when the REW was lower than 0.18 , while the daily $\mathrm{ET}_{\text {lawn }}$ started to decrease when it was lower than 0.14 . When REW was lower than 0.11 , the $\mathrm{T}_{\text {tree }}$ stayed at a relatively low level. The impacts of VPD was more evident on the diurnal $\mathrm{T}_{\text {tree }}$ than on the diurnal $\mathrm{ET}_{\text {lawn }}$. Wind speed had a scarce impact as it was relatively low in urban areas. This study clarifies the different responses of $\mathrm{ET}_{\text {lawn }}$ and $\mathrm{T}_{\text {tree }}$ to meteorological factors and soil water based on actual ET. The results are of great significance for the knowledge of urban forestry and urban hydrology.

Keywords: urban evapotranspiration; urban lawn; urban tree; meteorological factors; soil water

\section{Introduction}

It has been widely recognized that urban vegetation plays an important role in mitigating the urban heat island effect under the dual impact of global warming and rapid urbanization, and this process is directly related to urban ET [1-3]. Urban ET refers to the evaporation of water from different underlayers to the atmosphere in urban areas, which is the link between the urban water cycle and energy cycle. It can not only cool the surroundings by consuming a large proportion of available energy but also reduce urban runoff by larger water holding capacity, which cannot be ignored in the construction of sponge cities [4]. Therefore, increasing urban green space to increase ET is considered to be the most economical and effective means to deal with problems resulting from urbanization and climate change $[5,6]$.

It was believed that the ET in the urban environment was much smaller than that in the suburbs before the 1980s [7]. However, a small number of recent studies have shown that urban ET can be very large and an important part of the urban water budget [8-11]. In fact, vegetation coverage in many urban areas may be higher than that in adjacent suburbs. Urban ET could be increased by the enhancement of local and microscale advection in urban areas and irrigation [12]. With rapid global urbanization, some ecological and environmental problems (e.g., urban heat island effect, heat wave, urban flooding, etc.) have become increasingly prominent, most of which are closely related to ET. Therefore, some scholars have begun to focus on the field of urban ET. 
Vegetation ET is usually decided by the available energy (e.g., solar radiation), water vapor diffusion process (mainly decided by humidity and wind speed), available water, and physiological state of vegetation. In urban areas, albedo determines the net radiation received by the surface. Wang et al. found that albedo and surface temperature were the two factors that had the greatest impact on ET in Phoenix [13]. The diffusing conditions of water molecules is mainly affected by saturated vapor pressure deficit and wind speed $[14,15]$. The larger the saturated water vapor pressure deficit, the more easily the water molecules are diffused, thus leading to greater ET rates. Wind can promote the diffusion of water vapor, thus increasing the intensity of ET. Digiovanni et al. observed the ET at six sites in New York City and found that they were significantly different [1]. In total, $25 \%$ of the differences were attributed to vegetation types, and $40 \%$ of the differences were attributed to meteorological conditions. Kim et al. used the weighing method to observe the urban ET in Shuiying District, Busan [16]. They found that the correlation coefficient between the ET rate and dew point temperature was 0.63 , while the correlation with temperature, pressure, sunshine duration, and net radiation was higher than 0.5 .

Soil moisture is another important factor that determines the level of soil evaporation and available water for vegetation transpiration [17]. Water storage in urban areas decreases as soil on the urban surface is replaced by impervious water. Additionally, natural soils in urban green spaces, such as parks, are compacted by human activities and mixed with artificial materials as the industrial, commercial, and residential land expands $[18,19]$. The pore structure of the soil is thus changed. This will impede or delay water infiltration and interflow in urban areas [20,21]. Gregory et al. found that the infiltration of compacted soil due to construction activities was 70-99\% lower than that in low-impact development areas [22]. In addition, the deeper layers of green space in recreational areas are usually parts of a drainage system, which makes it difficult to store water in the soil. In this case, the hydrological process is different from the natural situation. In addition, the water supply capacity of soil in urban areas is reduced due to hydraulic resistance caused by paving materials, roofs, and parking lots [23]. When soil water supply is insufficient, the hydraulic resistance between the soil and the root system increases, which hinders the water transfer from the soil to leaf and results in the stomata closing and transpiration rate decreasing [24,25]. Voyde et al. found in their study at the University of Auckland that vegetation ET is an important part of urban latent heat flux when soil water is sufficient [26]. It has also been shown that the daily ET rate of olive trees is higher under humid conditions, such as increased precipitation or adequate irrigation [27,28]. Irrigation is an important water source for urban vegetation, especially in arid and semiarid areas $[29,30]$. Due to the presence of external water diversion and irrigation, urban ET exceeds precipitation in many cases [31-33]. Oke found that the potential ET of urban lawns was 1.3 times that of rural lawns as they had enough water supply from irrigation [34]. Lawn irrigation in the semiarid south of the United States can account for up to $70 \%$ of residential water use [35-38]. Therefore, to achieve good urban irrigation management, it is essential to have good knowledge of urban ET and its controlling factors.

However, the potential ET of urban lawns is mainly studied instead of actual ET. They are usually estimated with empirical crop coefficients [39], and the accuracy has not been verified $[38,40,41]$. In fact, unlike crops, urban lawns are generally heterogeneous (containing one or more types and not necessarily fully covering the ground), small in size, and shaded by trees and buildings [42]. Therefore, crop coefficients in agriculture may not be accurate for urban lawns. Trees in urban areas are either scattered individually or urban forests in parks. The ET of the latter has been studied more frequently in recent times as it is more similar to natural forests. Some researchers believe that the ET rate of urban trees may be higher than that of natural forests [43]. They suggest that individual trees in urban areas have more space, more soil, more solar radiation, and therefore a higher ET rate given they have sufficient water supply $[44,45]$.

However, due to lack of actual ET measurements, the impacts of meteorological factors and soil water on urban ET need further research and verification. In addition, varieties 
of grasses and trees are used in urban areas due to their ecological and environmental functions. It remains unknown whether lawns and trees respond to these factors differently in urban areas, which is important for urban heat island mitigation and sponge city building. Therefore, we measured the actual ET rate of an urban lawn $\left(\mathrm{ET}_{\text {lawn }}\right)$ using a Bowen ratio system and the transpiration rate of an urban tree $\left(\mathrm{T}_{\text {tree}}\right)$ by sap flow as well as synchronous meteorological parameters and soil water contents in the hot summer of a subtropical megacity, Shenzhen. We aimed to clarify the characteristics of urban ET from a lawn and a tree as well as their responses to climatic factors on daily and diurnal scales. The results will be of great significance for urban hydrology and forestry.

\section{Materials and Methods}

\subsection{Study Site}

Shenzhen is located in the southeast coast of Guangdong province, China $\left(113^{\circ} 45^{\prime} 44^{\prime \prime}\right.$ $\left.\mathrm{E} \sim 114^{\circ} 37^{\prime} 21^{\prime \prime} \mathrm{E}, 22^{\circ} 26^{\prime} 59^{\prime \prime} \mathrm{N} \sim 22^{\circ} 51^{\prime} 49^{\prime \prime} \mathrm{N}\right)$. It experiences a subtropical humid climate (cwa, Koppen climate classification), with a long summer and short winter. The annual average temperature is $23.0^{\circ} \mathrm{C}$. It is coldest in January $\left(15.4{ }^{\circ} \mathrm{C}\right)$ and hottest in July $\left(28.9^{\circ} \mathrm{C}\right)$. The annual average precipitation is $1935.8 \mathrm{~mm}$, with $86 \%$ of the rainfall occurring from April to September. The annual average sunshine duration is $1837.6 \mathrm{~h}$, and the annual solar radiation is $5225 \mathrm{MJ} \mathrm{m}^{-2}$. The annual average wind speed is $2.7 \mathrm{~m} \mathrm{~s}^{-1}$; it is lower in summer and approximately $2.1-2.2 \mathrm{~m} \mathrm{~s}^{-1}$ in July and August.

The study site was the campus of Peking University Shenzhen Graduate School (Figure 1). The study lawn was covered by Zoysia matrella (L.) Merr. Z. matrella spreads quickly and easily forms dense lawns. At the same time, it has strong drought tolerance, shade tolerance, and easy requirements for soil. Therefore, it is a widely used grass for urban greening in tropical and subtropical areas $[46,47]$. The study tree was Ficus concinna Miq., which is an evergreen tree that prefers a warm and rainy climate. It is widely distributed in subtropical regions of China as well as India, Vietnam, Myanmar, Malaysia, Philippines, and other countries. With its strong survival ability, fast growth, long life, and easy transplanting, it is an excellent tree species for afforestation. The observation period was from 4 April to 13 September 2018.
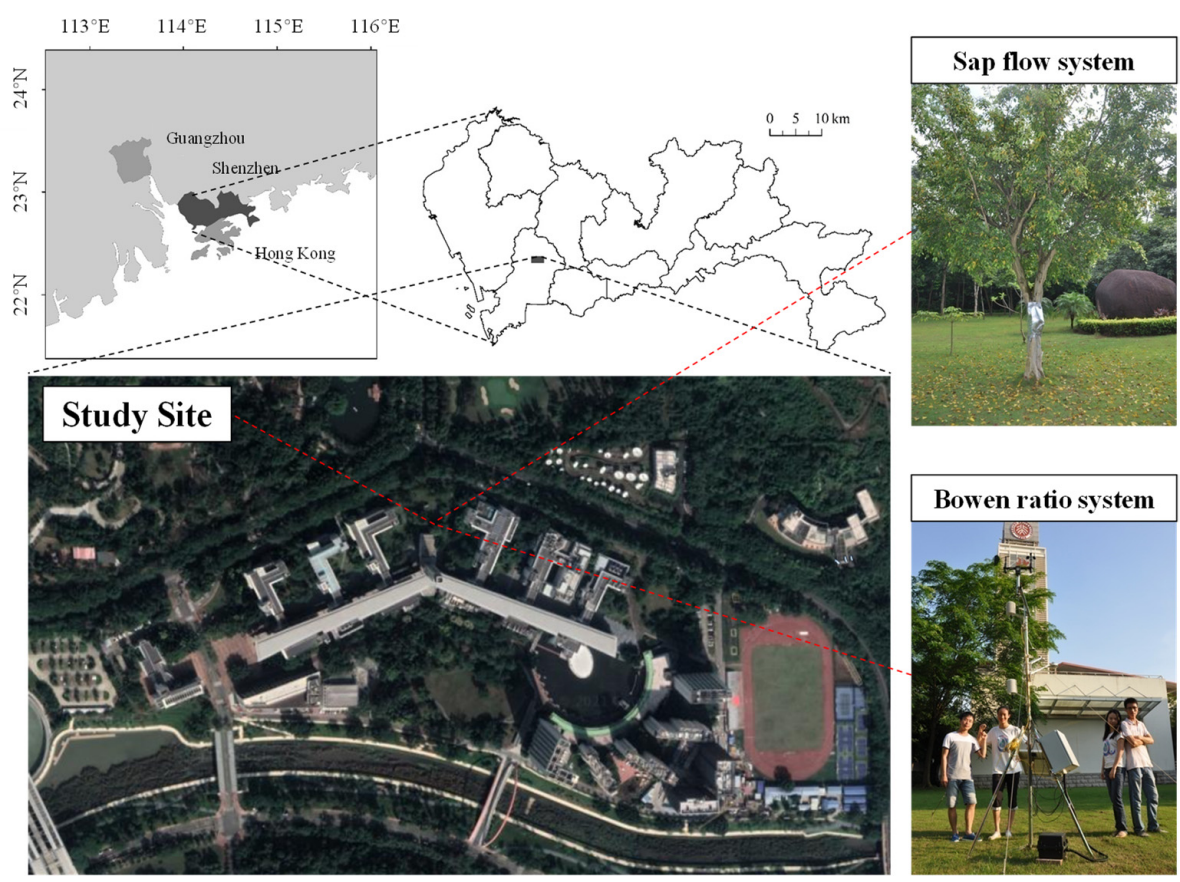

Figure 1. Location of the study site (left), the objective tree and the sap flow system (upper right), and the objective lawn and the Bowen ratio system (lower right). Figures were modified according to [48,49]. 


\subsection{Meteorological and Soil Water Content Measurements}

A Bowen ratio system was installed in the center of the Z. matrella lawn to observe meteorological parameters, including air temperature and relative humidity at the heights of 1.5 and $2 \mathrm{~m}$, solar radiation, net radiation, wind speed, wind direction, soil heat flux, and others (Figure 1 and Table 1). Each sensor took a measurement once every $1 \mathrm{~min}$. Then, the CR1000 datalogger (Campbell, Logan, UT, USA) was used for automated recording, and the system averaged and stored the data every $10 \mathrm{~min}$.

Table 1. Information of the sensors on the Bowen ratio system.

\begin{tabular}{|c|c|c|c|}
\hline Parameters & Sensors & Height (m) & Accuracy \\
\hline $\begin{array}{l}\text { Relative humidity } \\
\text { Air temperature }\end{array}$ & $\begin{array}{l}\text { 225-050YA, NOVALYNX, } \\
\text { Grass Valley, CA, USA }\end{array}$ & $2.0,1.5$ & $\pm 3 \%, \pm 0.6^{\circ} \mathrm{C}$ \\
\hline $\begin{array}{l}\text { Wind speed and } \\
\text { wind direction }\end{array}$ & $\begin{array}{l}\text { 200-WS-02, NOVALYNX, } \\
\text { Grass Valley, CA, USA }\end{array}$ & 2 & $\pm 0.2 \mathrm{~m} \mathrm{~s}^{-1}, \pm 3^{\circ}$ \\
\hline Solar radiation & $\begin{array}{l}\text { PYP-PA, APOGEE, Santa } \\
\text { Monica, CA, USA }\end{array}$ & 2 & $10 \sim 40 \mu \mathrm{VW}^{-1} \mathrm{~m}^{-2}$ \\
\hline Net radiation & $\begin{array}{c}\text { 240-100, NOVALYNX, Grass } \\
\text { Valley, CA, USA }\end{array}$ & 2 & $<4 \%$ \\
\hline Soil heat flux & $\begin{array}{l}\text { HFP01, HUKSEFLUX, Center } \\
\text { Moriches, NY, USA }\end{array}$ & $-0.05,-0.02$ & $50 \mu \mathrm{VW} \mathrm{W}^{-1} \mathrm{~m}^{-2}$ \\
\hline
\end{tabular}

SM300 soil moisture and temperature sensors (Delta-T Devices Ltd., Burwell, Cambridge, UK) were used at six depths of 5, 10, 20,25, 35, and $45 \mathrm{~cm}$ underground to monitor soil moisture. The CR1000 datalogger was also used to collect and store data each minute and store the average value every $10 \mathrm{~min}$. The Meteorological Bureau of Shenzhen Municipality provided precipitation data from the University Town Meteorology Station, which was just $500 \mathrm{~m}$ away from our study site.

\section{3. $E T_{\text {lawn }}$ and $T_{\text {tree }}$ Measurement}

The $\mathrm{ET}_{\text {lawn }}$ was calculated by parameters based on the Bowen ratio system. The $\mathrm{T}_{\text {tree }}$ was measured by the sap flow system. The sap flow probes (SF-L probe sensor, Ecomatik, Munich, Bavaria, Germany) were installed northward at the height of the tree chest. The CR1000 datalogger recorded the temperature difference between the probes every minute, then automatically averaged and stored the data every $5 \mathrm{~min}$. The data were recorded from April to September 2018.

\subsection{Data Analysis and Parameter Calculation}

The $\mathrm{ET}_{\text {lawn }}$ was calculated based on the Bowen ratio energy balance [50]:

$$
E T=\frac{R_{n}-G}{L(1+\beta)}
$$

where $E T$ is the evapotranspiration rate $\left(\mathrm{mm} \mathrm{s}^{-1}\right), R_{\mathrm{n}}$ is the net radiation $\left(\mathrm{W} \mathrm{m}^{-2}\right), G$ is the soil heat flux $\left(\mathrm{W} \mathrm{m}^{-2}\right), L$ is the latent heat coefficient of vaporization $\left(\mathrm{J} \mathrm{kg}^{-1}\right)$, and $\beta$ is the Bowen ratio:

$$
\beta=\frac{H}{L E}=\frac{\rho C_{p} K_{h} \frac{\partial T_{a}}{\partial z}}{\varepsilon L / P \rho K_{w} \frac{\partial e}{\partial z}}=\gamma \frac{\Delta T_{a}}{\Delta e}=\frac{C_{p} \Delta T_{a}}{L \Delta q}
$$

where $\rho$ is the air density $\left(\mathrm{kg} \mathrm{m}^{-3}\right) ; C_{\mathrm{p}}$ is the specific heat of air at constant pressure $\left(\mathrm{kJ} \mathrm{kg}^{-1}{ }^{\circ} \mathrm{C}^{-1}\right) ; \varepsilon$ is the molecular weight ratio of water vapor to dry air, which is a constant $0.622 ; P$ is the pressure $(\mathrm{kPa}) ; \gamma$ is the hygrometer constant; $\Delta T_{\mathrm{a}}, \Delta e$, and $\Delta q$ are the air temperature difference, vapor pressure difference, and humidity difference between the two heights the air temperature and relative humidity are recorded, respectively. They were 2 and $1.5 \mathrm{~m}$ in this study.

Because $\beta$ is usually close to -1 before and after sunrise and sunset, when the temperature is low or when it rains, the calculated latent heat flux is always infinite and 
meaningless. According to the characteristics of ET, combined with the theoretical basis of the Bowen ratio energy balance method, the intraday abnormal latent heat flux and sensible heat flux were excluded and then interpolated synchronously [51].

According to Granier's empirical formula of liquid flow density [52], the sap flow density can be obtained:

$$
F_{d}=119 \times\left(\frac{\Delta T_{m}-\Delta T}{\Delta T}\right)^{1.231}
$$

where $F_{\mathrm{d}}$ is the instantaneous sap flow density $\left(\mathrm{g} \mathrm{m}^{-2} \mathrm{~s}^{-1}\right), \Delta T$ is the instantaneous temperature difference between the probes, and $\Delta T_{\mathrm{m}}$ is the maximum temperature difference throughout the day. To deal with the impacts of both night-time flow and drift on $\Delta T_{\mathrm{m}}$, the local maxima of $\Delta T_{\mathrm{m}}$ over a 10-day period were first calculated. Then, the new $\Delta T_{\mathrm{m}}$ was calculated by a linear regression between these local maxima and time. Following the first linear interpolation, the data points that were below the estimated values were eliminated, and another linear interpolation was made with the remaining data points [53,54].

The tree transpiration rate per unit canopy area $\left(T_{\mathrm{r}}, \mathrm{mm} \mathrm{h}^{-1}\right)$ can be calculated by the following formula:

$$
T_{r}=3.6 \times F_{d} \times A / S_{c}
$$

where $A$ is the sapwood area $\left(\mathrm{m}^{2}\right)$, which was approximately $0.048 \mathrm{~m}^{2}$ in this study. $S_{\mathrm{c}}$ is the canopy area, which was $28.274 \mathrm{~m}^{2}$ in this study.

Relative extractable water (REW) was used to express the soil water status. It was calculated by the volumetric soil water content (VWC) $[55,56]$.

$$
R E W=\left(V W C-V W C_{\min }\right) /\left(V W C_{\max }-V W C_{\min }\right)
$$

where $V W C_{\max }$ and $V W C_{\min }$ are the maximum and minimum measured $V W C$, respectively.

\section{Results}

\subsection{Meteorological Factors and Soil Water Conditions}

Based on the data from the Bowen ratio system, the daily radiation was abundant at our study site during the study period. The daily average solar radiation was $123.25 \mathrm{~W}$ $\mathrm{m}^{-2}$, and its maximum reached $227.78 \mathrm{~W} \mathrm{~m}^{-2}$ (Figure 2). There was no significant variance in the solar radiation among the months. The air temperature was relatively high at the study site. It was $27.59^{\circ} \mathrm{C}$ on average throughout the study period.

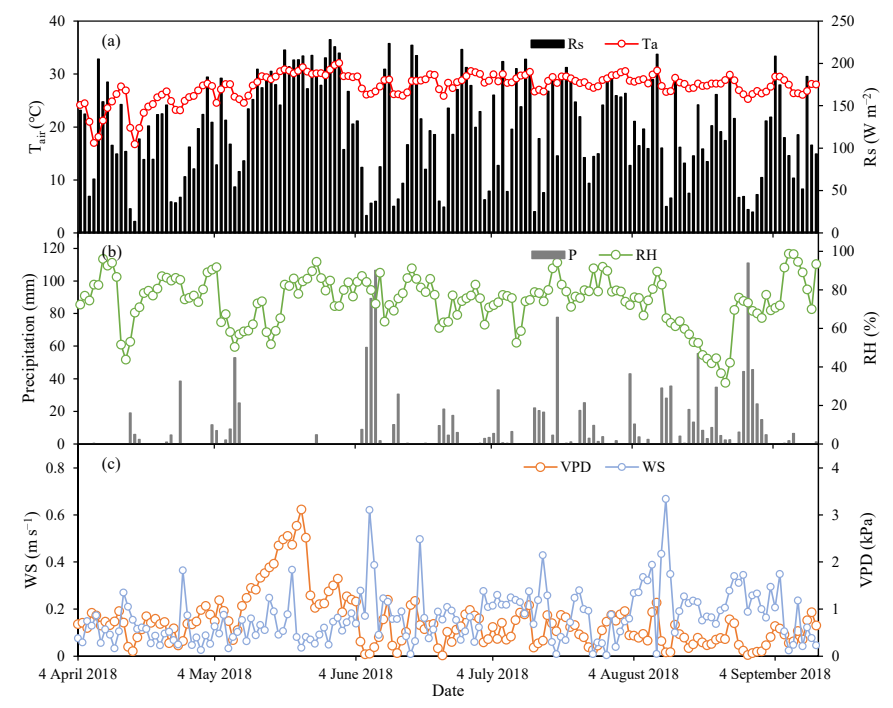

Figure 2. Daily values of (a) the air temperature $\left(T_{\text {air }}\right)$ and solar radiation $\left(R_{S}\right),(b)$ the precipitation $(\mathrm{P})$ and the relative humidity (RH), and (c) the vapor pressure deficit (VPD) and wind speed (WS) during the study period. 
The total precipitation was $1418.8 \mathrm{~mm}$ during the study period, and the annual precipitation in 2018 at our study site was $1859.2 \mathrm{~mm}$, which is close to the mean annual value in Shenzhen (1935.8 mm, according to Meteorological Bureau of Shenzhen Municipality). Abundant precipitation caused humid air, resulting in a high daily relative humidity (80.81\% on average and a maximum of $99.50 \%$ ).

Due to the high air temperature but high relative humidity, the daily VPD was $0.73 \mathrm{kPa}$ on average and was within approximately $1 \mathrm{kPa}$ most of the time. It increased in May, when the air temperature was higher and relative humidity decreased. Additionally, as the study site was located in the center of the urban area, the wind speed was relatively low. The daily average wind speed throughout the study period was only $0.15 \mathrm{~m} \mathrm{~s}^{-1}$.

The soil water conditions during the study period are shown in Figure 3. Soil water contents for all soil depths increased from April to early May and then declined quickly until early June. It fluctuated within a similar range from June to September. The larger fluctuation of volumetric soil water contents occurred at the depth of 20 and $25 \mathrm{~cm}$, coincident with rainfall events. This indicates that precipitation mainly recharged the surface soil layer (20-25 cm beneath the surface). In urban areas, the deep soil is usually mixed with artificial materials $[18,19]$. At our study site, there was a landfill layer made of construction wastes at the depth of $20-30 \mathrm{~cm}$ beneath the surface. Thus, the water infiltration from the surface to the deep soil was slowed down.

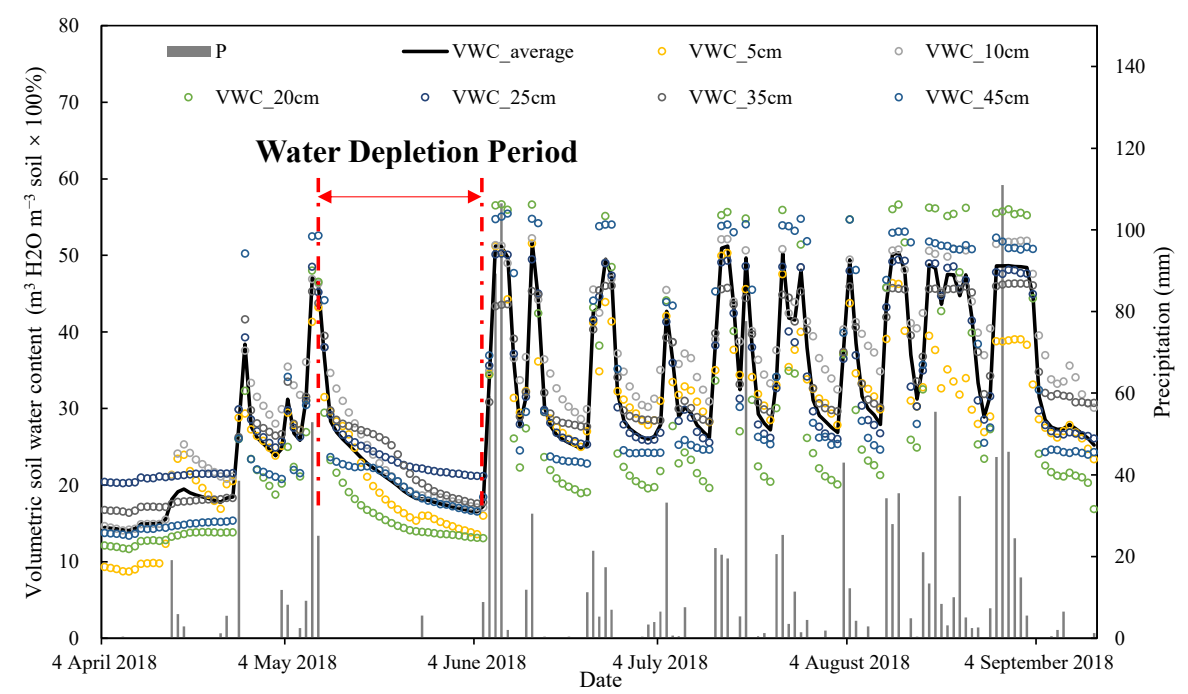

Figure 3. Trends of volumetric soil water contents (VWC, $\mathrm{m}^{3} \mathrm{H}_{2} \mathrm{O} \mathrm{m} \mathrm{m}^{-3}$ soil $\times 100 \%$ ) for all measurement depths of soil precipitation throughout the study period.

The average values of VWC and REW at different depths were used for the analysis as lawns and trees may use water at different depths. As can be seen, there was a long drying period between 9 May and 5 June, during which there was only one rainy day (26 May, $5.6 \mathrm{~mm}$ ). The soil continued to become dryer during this period. Therefore, we defined this period as a water depletion period to better evaluate the response of $\mathrm{ET}_{\text {lawn }}$ and $\mathrm{T}_{\text {tree }}$ to soil water conditions.

\subsection{Responses of Diurnal $E T_{\text {lawn }}$ and $T_{\text {tree }}$ to Meteorological Factors and Soil Water}

To investigate the response of diurnal $\mathrm{ET}_{\text {lawn }}$ and $\mathrm{T}_{\text {tree }}$ to meteorological factors and water, we selected three typical days with similar $R_{s}$ and VPD but different REW. The three days were 8 April (the dry day before the rainy days between 15 April and 9 May; $\mathrm{R}_{\mathrm{s}}$ : $205.04 \mathrm{~W} \mathrm{~m}^{-2}$, VPD: $0.86 \mathrm{kPa}$, and REW: 0.01), 13 May (the day after the rainy days between 15 April and 9 May; $\mathrm{R}_{\mathrm{s}}$ : $193.18 \mathrm{~W} \mathrm{~m}^{-2}$, VPD: $1.41 \mathrm{kPa}$, and REW: 0.31), and 28 May (the day after continuous soil water decrease; $\mathrm{R}_{\mathrm{s}}: 206.57 \mathrm{~W} \mathrm{~m}^{-2}$, VPD: $1.12 \mathrm{kPa}$, and REW: 0.10). 
First, the dynamics of the diurnal $\mathrm{ET}_{\text {lawn }}$ was similar in pattern to the $\mathrm{R}_{\mathrm{s}}$ in the three days (Figure 4). The peak of $\mathrm{ET}_{\text {lawn }}$ in the wet day was larger (13 May) than the two dry days (8 April and 28 May), and the peaks of $\mathrm{ET}_{\text {lawn }}$ in the two dry days started to decrease before the peak of $R_{\mathrm{S}}$, which might reveal the restriction of water. Diurnal VPD had weaker impacts on $\mathrm{ET}_{\text {lawn }}$ compared to $\mathrm{R}_{\mathrm{s}}$. In contrast, the diurnal $\mathrm{T}_{\text {tree }}$ was affected by both $R_{S}$ and VPD in the three days. After it reached its peak around the $R_{S}$ peak time, the $T_{\text {tree }}$ maintained a relatively high rate until the peak of VPD (Figure 4). Second, the daily $\mathrm{ET}_{\text {lawn }}\left(\mathrm{T}_{\text {tree }}\right)$ increased from $3.62 \mathrm{~mm} \mathrm{~d}^{-1}\left(0.54 \mathrm{~mm} \mathrm{~d}^{-1}\right)$ on 8 April to $5.55 \mathrm{~mm} \mathrm{~d}^{-1}$ (3.53 $\mathrm{mm} \mathrm{d}^{-1}$ ) on 13 May due to the increase in REW. Afterwards, the daily $\mathrm{ET}_{\text {lawn }}$ decreased to $4.16 \mathrm{~mm} \mathrm{~d}^{-1}\left(0.49 \mathrm{~mm} \mathrm{~d}^{-1}\right)$ on 28 May as the soil water gradually decreased. This revealed a strong controlling effect of soil water on the ET from the urban lawn and tree, and the impacts of REW on the $T_{\text {tree }}$ were highly significant. $T_{\text {tree }}$ on the two dry days was slower than $0.05 \mathrm{~mm} \mathrm{~h}^{-1}$ throughout the day.

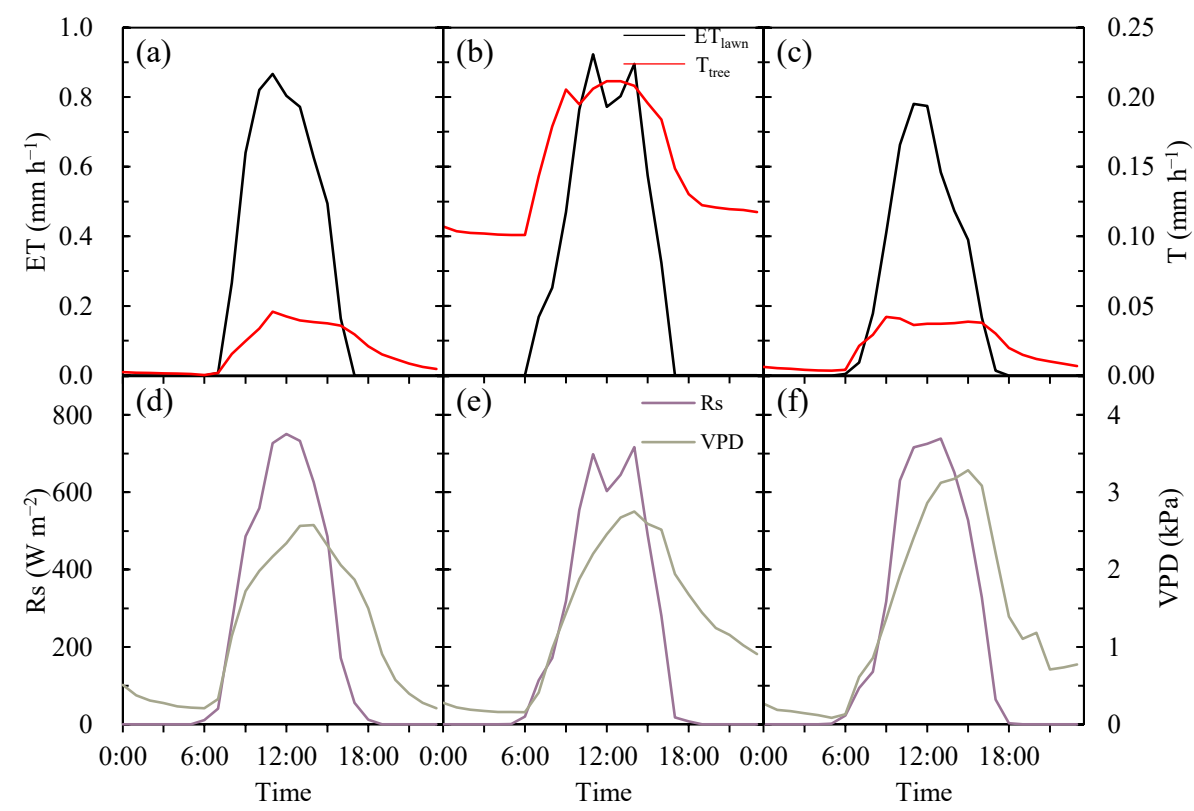

Figure 4. Diurnal courses of the evapotranspiration of urban lawn $\left(\mathrm{ET}_{\text {lawn }}\right)$, transpiration of urban tree $\left(T_{\text {tree }}\right)$, solar radiation $\left(R_{s}\right)$, and vapor pressure deficit $(V P D)$ on three typical days with similar $\mathrm{R}_{\mathrm{S}}$ and VPD but different REW: 8 April (a,d), 13 May (b,e), and 28 May (c,f).

As the $\mathrm{ET}_{\text {lawn }}$ was measured and calculated based on the Bowen ratio balance method, it was zero in the nighttime as the radiation was around 0 . However, there was obvious nocturnal sap flow for the tree. Though we did not find other studies that could confirm the nocturnal transpiration of $F$. concinna, many studies have observed this phenomenon for other urban trees [57-59]. Nocturnal sap flow is composed of refilling and transpiration. According to Fisher et al., it is used for refilling when nighttime VPD is low and for transpiration when nighttime VPD is high, and there is a strong correlation between sap flow and VPD [60]. In our study site, the nighttime VPD could be as high as $1 \mathrm{kPa}$ in nighttime in the three typical days (Figure 4). Moreover, the nocturnal sap flow was significantly correlated to VPD (Figure 5). Therefore, we would deduce there was strong nocturnal transpiration for our study tree, and it was mainly controlled by VPD. More precise separation of refilling and transpiration needs further study. 

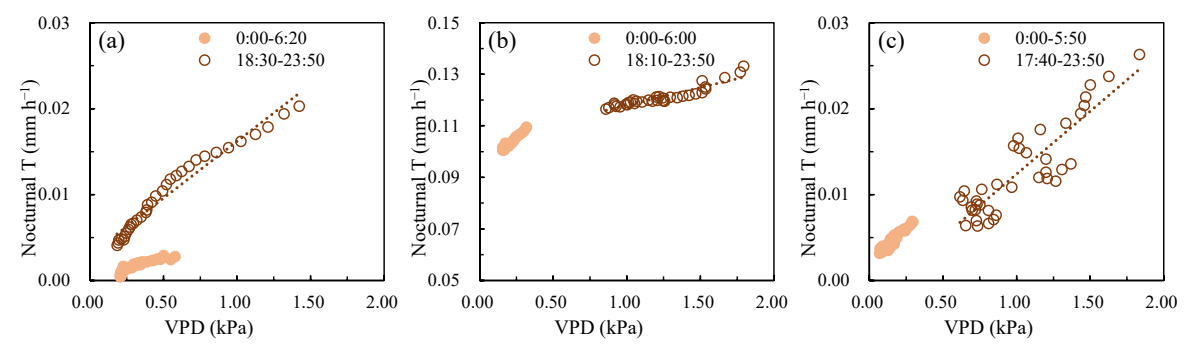

Figure 5. Nocturnal transpiration rate of the urban tree and vapor pressure deficit (VPD) in the three typical days: (a) 8 April, (b) 13 May, and (c) 28 May. The nighttime was defined according to the solar radiation $\left(\mathrm{R}_{\mathrm{S}}<10 \mathrm{~W} \mathrm{~m}^{-2}\right)$. All of the nighttime sap flow was attributed to transpiration in this study, which may lead to some overestimation of nocturnal transpiration.

\subsection{Responses of Daily $E T_{\text {lawn }}$ and $T_{\text {tree }}$ to Meteorological Factors and Soil Water}

The average daily $\mathrm{ET}_{\text {lawn }}$ was $2.50 \mathrm{~mm} \mathrm{~d}^{-1}$ throughout the study period (Figure 6). The maximum was $5.96 \mathrm{~mm} \mathrm{~d}^{-1}$ on 19 May, and the minimum was $0.18 \mathrm{~mm} \mathrm{~d}^{-1}$ on 16 April when the radiation was weak during precipitation. It was relatively higher before June, then fluctuated within $0.33-3.96 \mathrm{~mm} \mathrm{~d}^{-1}$ between June and September.

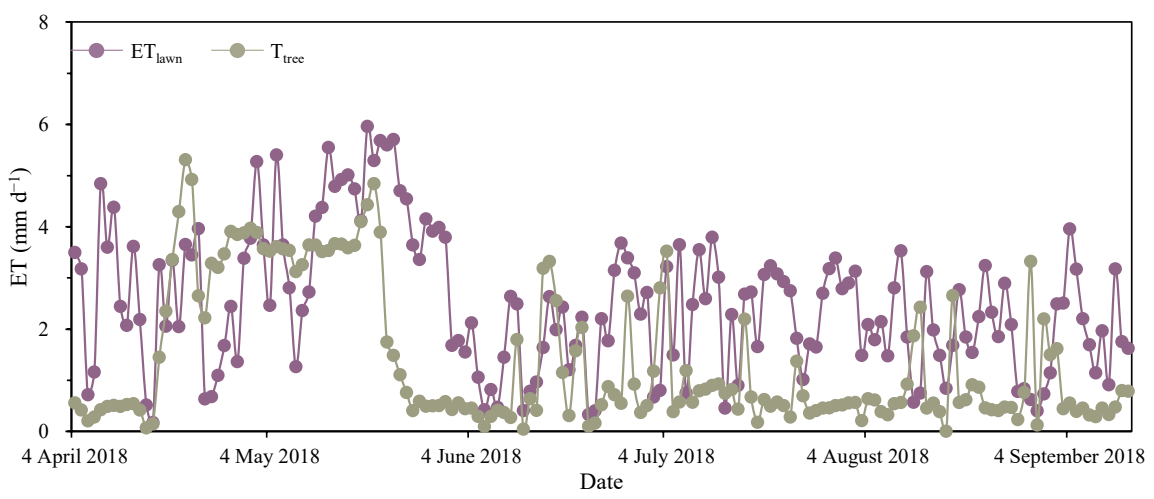

Figure 6. Daily evapotranspiration of the urban lawn $\left(\mathrm{ET}_{\mathrm{lawn}}\right)$ and daily transpiration of the urban tree $\left(\mathrm{T}_{\text {tree}}\right)$ at the study site during the study period (4 April 2018 to 13 September 2018).

The average daily $\mathrm{T}_{\text {tree }}$ was $1.40 \mathrm{~mm} \mathrm{~d}^{-1}$ throughout the study period. The maximum was $5.31 \mathrm{~mm} \mathrm{~d}^{-1}$ on 21 April, and the minimum was $0.01 \mathrm{~mm} \mathrm{~d}^{-1}$ on 16 August during a long period of rainy days. The $\mathrm{T}_{\text {tree }}$ was also higher before June. Unlike the $\mathrm{ET}_{\text {lawn }}$, the $\mathrm{T}_{\text {tree }}$ did not fluctuate frequently during this period. It increased from $16 \mathrm{April}$ and then stayed at a high level before 20 May. Between June and September, the daily $\mathrm{T}_{\text {tree }}$ fluctuated within $0.01-3.52 \mathrm{~mm} \mathrm{~d}^{-1}$.

The daily $\mathrm{ET}_{\text {lawn }}$ and $\mathrm{T}_{\text {tree }}$ responded differently to meteorological factors and soil water (Table 2). During the whole study period, the daily $\mathrm{ET}_{\text {lawn }}$ was significantly affected by $R_{s}$ as calculated by the Bowen ration energy balance method. It was also significantly affected by VPD, indicating the importance of water vapor diffusion conditions. However, wind speed had a scarce impact on the $\mathrm{ET}_{\text {lawn }}$ as it was quite low in urban areas. REW also had a scarce impact on the $\mathrm{ET}_{\text {lawn }}$. This indicates that energy and diffusion conditions were the main restrictions to $\mathrm{ET}_{\text {lawn, }}$, while soil water was sufficient for the lawn at our study site.

During the whole study period, the daily $T_{\text {tree }}$ was not significantly correlated to $R_{S}$. However, it was significantly restricted by REW. VPD also had significant impacts on it, but the partial correlation coefficient and significance were weaker than those of $\mathrm{ET}_{\text {lawn }}$. Wind speed still had a scarce impact on the daily $\mathrm{T}_{\text {tree }}$. Therefore, diffusion conditions and soil water conditions were the main restrictions to $T_{\text {tree, }}$ while energy was sufficient at our study site. 
Table 2. Partial correlation coefficients of daily evapotranspiration of the urban lawn $\left(\mathrm{ET}_{\text {lawn }}\right)$ and daily transpiration of the urban tree $\left(\mathrm{T}_{\text {tree }}\right)$ to meteorological factors $\left(\mathrm{R}_{\mathrm{S}}, \mathrm{VPD}\right.$, and $\left.\mathrm{WS}\right)$ and soil water conditions (REW) during the whole study period (4 April 2018 to 13 September 2018) and water depletion period (9 May 2018 to 5 June 2018).

\begin{tabular}{cccccc}
\hline \multicolumn{2}{c}{ Meteorological Factors/Water } & $\mathbf{R}_{\mathbf{s}}$ & VPD & WS & REW \\
\hline \multirow{2}{*}{$\mathrm{ET}_{\text {lawn }}$} & Whole period & $0.560^{* * *}$ & $0.505^{* * *}$ & 0.212 & -0.010 \\
& Water depletion period & $0.823^{* * *}$ & $0.696^{* * *}$ & -0.347 & $0.758^{* * *}$ \\
\hline \multirow{2}{*}{$\mathrm{T}_{\text {tree }}$} & Whole period & -0.229 & $0.360^{* *}$ & -0.060 & $0.327^{*}$ \\
& Water depletion period & 0.059 & $0.520^{* *}$ & $-0.417^{*}$ & $0.773^{* * *}$ \\
${ }^{*} p<0.05,{ }^{* *} p<0.011^{* * *} p<0.001$. & & & &
\end{tabular}

Partial correlation analysis was also conducted for the water depletion period. Different from the results during the whole study period, the $\mathrm{ET}_{\text {lawn }}$ was significantly correlated with $R_{s}, V P D$, and REW during the water depletion period. This indicates that the $\mathrm{ET}_{\text {lawn }}$ was restricted by energy, water vapor diffusion conditions, and soil water contents. When REW was higher than 0.14 , the $\mathrm{R}_{\mathrm{S}}$ and VPD were weaker, which might explain the decreased $\mathrm{ET}_{\text {lawn }}$. The impacts of VPD and REW on the $\mathrm{T}_{\text {tree }}$ were stronger during the water depletion period. Wind speed had significant negative impacts on the $T_{\text {tree }}$. The prevailing wind is north-northeast in summer in Shenzhen. In the north-northeast of the study site, there was a large area of green space, including a golf course, while there were buildings in the west, south, and east of the study site. Therefore, the wind carried moisture from the north-northeast and then depressed the transpiration of the tree. The wind had weaker impacts on the lawn, perhaps due to the fact that the lawn was much lower.

During the water depletion period, the daily REW decreased gradually and the $5.6 \mathrm{~mm}$ precipitation did not recharge the soil water efficiently (Figure 7a). Meanwhile, the daily $\mathrm{ET}_{\text {lawn }}$ was stable between 9 May and 23 May and even showed a slight increase. It was $5.70 \mathrm{~mm} \mathrm{~d}^{-1}$ on 23 May, then decreased quickly. On $5 \mathrm{June}$, it was only $1.06 \mathrm{~mm} \mathrm{~d}^{-1}$. Similarly, the $\mathrm{T}_{\text {tree }}$ was also relatively stable at the beginning of the drought period. Nevertheless, it decreased after 20 May, three days earlier than the $\mathrm{ET}_{\text {lawn }}$. It decreased quickly from 4.84 to $0.41 \mathrm{~mm} \mathrm{~d}^{-1}$ on 26 May. After that, the $T_{\text {tree }}$ stayed at a relatively low level $\left(0.41-0.59 \mathrm{~mm} \mathrm{~d}^{-1}\right)$. Although the REW was lower than 0.4 from 11 May onwards, a threshold value that induces stomatal closure in many trees [61], the $\mathrm{ET}_{\text {lawn }}$ and $\mathrm{T}_{\text {tree }}$ in our study site did not decline immediately. This may indicate that the grass and tree species in our study site may get higher endurability of water pressure.
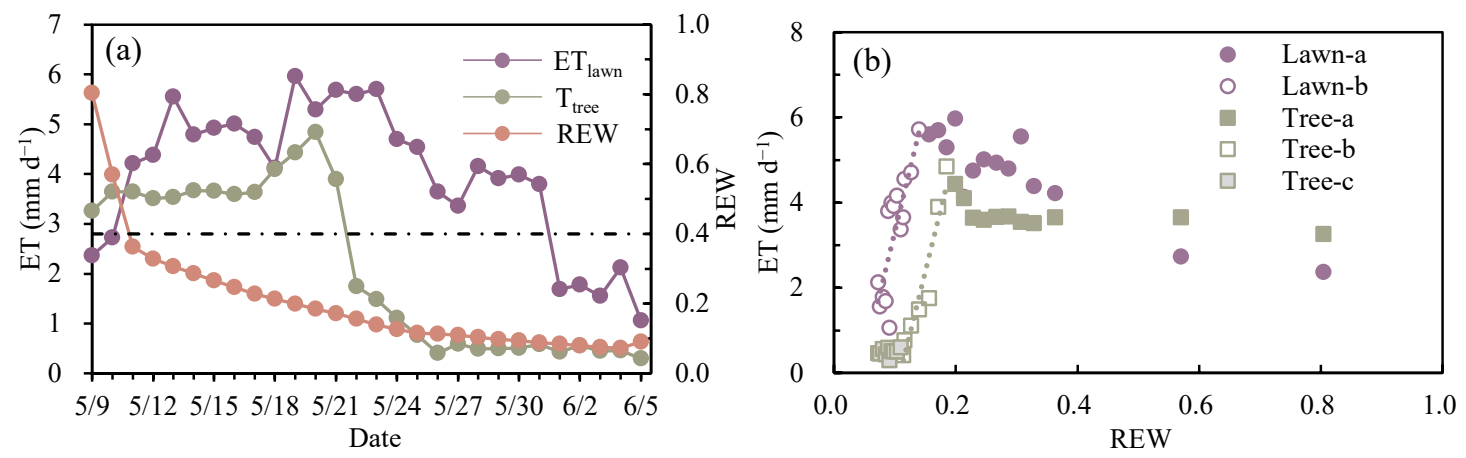

Figure 7. Response of urban lawn evapotranspiration $\left(\mathrm{ET}_{\mathrm{lawn}}\right)$ and urban tree transpiration $\left(\mathrm{T}_{\text {tree }}\right)$ to relative extractable water (REW). (a) Daily variation during the water depletion period (9 May 2018 to 5 June 2018). The dashed line means REW of 0.4, a threshold value that induces stomatal closure in many trees. (b) Different stages of ET and T under different REW; lawn_a: $E_{\text {lawn }}$ when water is sufficient, lawn_b: $\mathrm{ET}_{\text {lawn }}$ declined with the reduction in REW, Tree_a: $\mathrm{T}_{\text {tree }}$ when water is sufficient, Tree_b: $T_{\text {tree }}$ declined with the reduction in REW, Tree_c: stable $T_{\text {tree }}$ when REW is relatively low. 
Figure $7 \mathrm{~b}$ shows how $\mathrm{ET}_{\text {lawn }}$ and $\mathrm{T}_{\text {tree }}$ decreased with the reduction in REW. As can be seen, $\mathrm{ET}_{\text {lawn }}$ decreased almost linearly with the reduction in REW when it was lower than 0.14. When REW was higher than 0.14, the ET even decreased with increasing REW, which can probably be explained by the lower radiation on rainy days. In contrast, $\mathrm{T}_{\text {tree }}$ decreased almost linearly with the reduction in REW when $0.11<\mathrm{REW}<0.18$. When REW was lower than 0.11 , the $\mathrm{T}_{\text {tree }}$ stayed at a low level. The $\mathrm{T}_{\text {tree }}$ was almost similar when REW was higher than 0.18 , which indicates that the impacts of other factors may be weaker when soil water is sufficient.

\section{Discussion}

\subsection{Intensities of $E T_{\text {lawn }}$ and $T_{\text {tree }}$}

The average daily $\mathrm{ET}_{\text {lawn }}$ was $2.50 \mathrm{~mm} \mathrm{~d}^{-1}$ throughout the study period in this study. In another study, also conducted in Shenzhen, Zhang et al. measured the ET of a Zoysia tenuifoli green roof and a Callisia repens green roof using the three temperature model [62]. They found the average daytime ET rates of 0.31 and $0.29 \mathrm{~mm} \mathrm{~h}^{-1}$ for the two kinds of grasses after rainfall in April to May. They were much lower than daytime $\mathrm{ET}_{\text {lawn }}$ $\left(0.46 \mathrm{~mm} \mathrm{~h}^{-1}\right)$ in the wet day in our study. Yu et al. also measured the daytime ET of a Sedum Lineare green roof using the three temperature model in Shenzhen [63]. They found the rate of $0.04-0.54 \mathrm{~mm} \mathrm{~h}^{-1}$ on sunny summer days and $0.03-0.09 \mathrm{~mm} \mathrm{~h}^{-1}$ on sunny winter days. In Florida, which also experiences a subtropical humid climate, a Paspalum notatum lawn consumed 834 and $822 \mathrm{~mm}$ of water through ET in 2011 and 2012, respectively. It was also not affected by water, considering there was $700 \mathrm{~mm}$ more precipitation in 2012 than 2011 [64]. In cities with a Mediterranean climate, the ET of the lawn even reached as high as $10 \mathrm{~mm} \mathrm{~d}^{-1}$ on sunny summer days $[65,66]$. This was much larger than the $\mathrm{ET}_{\text {lawn }}$ in our study. The water vapor could diffuse efficiently as it was relatively dry in summer. Additionally, the lawns were irrigated well in these studies, avoiding water stress. In cities at higher latitude that experience a dry temperate continental climate, the Lolium perenne lawn and Cynodon dactylon lawn could consume 3.10 and $4.98 \mathrm{~mm} \mathrm{~d}^{-1}$ (average during 2013 to 2015) water in summer, respectively $[67,68]$. The daily ET rate of six different species of Sedum in New York was $1.93 \mathrm{~mm} \mathrm{~d}^{-1}$ throughout the year [1]. Overall, the ET of urban lawns depends on a variety of parameters, such as grass species, irrigation, and climate, thus making it difficult to compare them with one another.

The transpiration of urban tree also depends on the climate, species, size of the tree, etc. The average daily $\mathrm{T}_{\text {tree }}$ was $1.40 \mathrm{~mm} \mathrm{~d}^{-1}$ in this study. Pataki et al. found that the Ficus microcarpa consumed $89.9 \mathrm{~kg}_{\text {tree }} \mathrm{d}^{-1} \mathrm{~d}^{-1}$ water through transpiration [69]. This was relatively higher among the tree species in the Los Angeles Arboretum. It was also much higher than the $T_{\text {tree }}$ in our study (equal to $39.58 \mathrm{~kg}$ tree $^{-1} \mathrm{~d}^{-1}$ ). The radiation in Los Angeles was abundant in summer, and irrigation supplemented the soil water well. The dryer air and higher VPD might promote transpiration. In the city of Miyoshi, Aichi Prefecture, which experiences a similar climate to our study site, the transpiration of Zelkova serrata was slightly lower than the F. concinna in our study, which likely indicates the impact of tree species and size [70].

Most of the previous studies have found that trees consume more water than shrubs and lawns under natural conditions [71-74]. However, the $\mathrm{T}_{\text {tree }}$ was lower than the $\mathrm{ET}_{\text {lawn }}$ in our study. This is due to the fact that the $\mathrm{ET}_{\text {lawn }}$ included the transpiration of the grass and the evaporation of the canopy and soil. Evaporation could count for 28\% [75], 64\% [76], and $12-27 \%$ [77] of the ET $_{\text {lawn }}$ in previous studies. In Huanjiang, Guangxi, which also experiences a subtropical humid climate, the evaporation contributed $36 \%$ of the $\mathrm{ET}_{\text {lawn }}$ in the growing season [78]. As the precipitation at our study site was highly abundant, the evaporation could also significantly contribute to the $\mathrm{ET}_{\text {lawn }}$. Meanwhile, the transpiration of the tree was obtained by sap flow (then divided by canopy area to obtain the rate in $\mathrm{mm} \mathrm{h}^{-1}$ or $\mathrm{mm} \mathrm{d}^{-1}$ to better compare with the lawn), which could not measure the evaporation of canopy interception, thus underestimating the total ET of the tree. Therefore, the intensity of $\mathrm{ET}_{\text {lawn }}$ and $\mathrm{T}_{\text {tree }}$ is not quite comparable in our study. Additionally, the 
root systems of trees are usually deeper under natural conditions and are thus capable of utilizing more soil water [79-81]. Due to compression, the soil volume density is large and the structure is poor in urban areas. As a result, the usable space in soil for roots is small. This may have a greater impact on trees [82-84] and lead to lower transpiration rates. Some studies have found that the transpiration rate of trees was still lower than that of lawns in urban areas, even when the canopy interception of trees was taken into account [68].

\subsection{Response of $E T_{\text {lawn }}$ and $T_{\text {tree }}$ to Meteorological Factors}

VPD significantly promoted both daily $\mathrm{ET}_{\text {lawn }}$ and $\mathrm{T}_{\text {tree }}$ in this study. VPD could increase the water demand of ambient air and thus promote ET [85,86]. However, it had greater impacts on $\mathrm{T}_{\text {tree }}$ than $\mathrm{ET}_{\text {lawn }}$ on a diurnal scale. The effect of VPD and radiation on transpiration depends on the coupling between the vegetation canopy and the surrounding atmosphere [9]. The aerodynamic roughness of a tree canopy is usually higher, which can effectively promote the turbulent exchange between the air on the leaf surface and the surrounding atmosphere. Therefore, tree canopy transpiration is usually related to atmospheric conditions, and VPD is an important controlling factor of tree canopy transpiration $[87,88]$. However, the aerodynamic roughness of the lawn canopy is usually low, and there is usually a moist air layer on the surface of grasses, which decouples the grass leaf from the atmosphere to a certain extent. Therefore, net radiation is usually the main driving force of grassland evapotranspiration, and the effect of saturated vapor pressure difference is relatively weak $[88,89]$.

\subsection{Response of $E T_{\text {lawn }}$ and $T_{\text {tree }}$ to Soil Water}

The impacts of soil water were stronger on $\mathrm{T}_{\text {tree }}$ than $\mathrm{ET}_{\text {lawn }}$ in urban areas in our study. Some studies have found that Ficus trees have lower water use efficiency [90,91]. More importantly, urban soil usually has a large volume density and poor structure, which greatly restricts the development of urban tree root space [82-84]. As there was a layer of construction waste at a depth of 20-30 cm beneath the surface, the precipitation replenished water more for surface soil layers, making it easier for grass with a shallow root system to obtain water. Trees with limited root system space will face more frequent and severe water pressure, resulting in decreased stomatal conductance and transpiration levels [92]. Increasing the water permeability of the surrounding underlying surface and improving the soil looseness in the planting area of trees can significantly increase the water available to the roots of trees $[93,94]$.

Throughout our study period, the $T_{\text {tree }}$ was $227.68 \mathrm{~mm}$ and consumed $6.44 \mathrm{~m}^{3}$ water in total (the canopy area was $28.274 \mathrm{~m}^{2}$ ). The contemporary precipitation was $1418.8 \mathrm{~mm}$, which meant that the $T_{\text {tree }}$ would consume the precipitation in the area of $1.20 \mathrm{~m}$ radius around the tree without competing with other plants $\left(\sqrt{\left(6.44 m^{3} / 1418.8 m m\right) / \pi}\right)$. During the water depletion period, however, the transpiration $(56.54 \mathrm{~mm})$ would consume the precipitation in the area of $2.23 \mathrm{~m}$ radius around the tree without competing with other plants (the precipitation before the water depletion period was $183.1 \mathrm{~mm}$ in total, and the contemporary $\mathrm{T}_{\text {tree }}$ was $80.43 \mathrm{~mm}$; therefore, the radius was $\left.\sqrt{\left(1.60 \mathrm{~m}^{3} /(183.1 \mathrm{~mm}-80.43 \mathrm{~mm})\right) / \pi}\right)$. However, the DBH of the tree was only $30 \mathrm{~cm}$. This indicates that the root system must be relatively extended in order to obtain soil water, especially during the water depletion period. However, it is usually difficult to accurately measure the root system development of urban trees [70]. Additionally, the analysis above assumes that all the precipitation was used for transpiration, and there was no competition surrounding the tree. In fact, precipitation would also be consumed by evaporation through canopy interception and soil as well as the transpiration of other surrounding vegetations. Therefore, the root system size requirement calculated above for urban trees may still be underestimated.

\section{Conclusions}

Based on the Bowen ratio system and sap flow system, this study measured the actual ET rates of an urban lawn and an urban tree as well as synchronic meteorological factors 
and soil water contents in the hot summer of a subtropical megacity, Shenzhen. The results showed that the daily average $\mathrm{ET}_{\text {lawn }}$ and $\mathrm{T}_{\text {tree }}$ were 2.50 and $1.40 \mathrm{~mm} \mathrm{~d}^{-1}$, respectively, throughout the whole study period. Throughout the study period, the daily $\mathrm{ET}_{\text {lawn }}$ was mainly decided by $\mathrm{R}_{\mathrm{s}}(\mathrm{r}=0.560, p<0.001)$ and VPD $(\mathrm{r}=0.505, p<0.001)$, while the daily $\mathrm{T}_{\text {tree }}$ was mainly decided by VPD $(\mathrm{r}=0.360, p<0.01)$ and REW $(\mathrm{r}=0.327, p<0.05)$. The $\mathrm{ET}_{\text {lawn }}$ was more restricted by energy, and $\mathrm{T}_{\text {tree }}$ was more restricted by soil water. The daily $\mathrm{ET}_{\text {lawn }}$ started to decrease linearly with the reduction in REW when it was lower than 0.14 during the water depletion period. The daily $\mathrm{T}_{\text {tree }}$ started to decrease linearly with the reduction in REW when it was lower than 0.18 . When REW was lower than 0.11 , the $\mathrm{T}_{\text {tree }}$ stayed at a relatively low level. Wind speed had a scarce impact as it was relatively low in urban areas. These results are not only useful for urban irrigation management but also important for adaptation to climate change and urbanization.

Author Contributions: Z.Z. analyzed the data, presented the results with graphs and tables, and wrote the paper. C.Y. revised the manuscripts and provided some useful suggestions in the results and discussion section. L.Y., X.J., J.D. (Jinshan Ding) and J.D. (Junjie Ding) maintained the observation field and collected the data. G.Q. designed the experiment and was the final corresponding author. All authors have read and agreed to the published version of the manuscript.

Funding: This research was funded by the National Natural Science Foundation of China, grant number 42001022, and Science and Technology Planning Project of Shenzhen Municipality, grant numbers JCYJ20180504165440088 and GXWD20201231165807007-20200827105738001.

Acknowledgments: The authors would like to express their great thanks to Shenglin Tan, Xiaohui $\mathrm{Yu}$, and Bei Wang for their assistance in the field study. Great thanks also goes to the Meteorological Bureau of Shenzhen Municipality for their data supports.

Conflicts of Interest: The authors declare no conflict of interest.

\section{References}

1. DiGiovanni, K.; Montalto, F.; Gaffin, S.; Rosenzweig, C. Applicability of classical predictive equations for the estimation of evapotranspiration from urban green spaces: Green roof results. J. Hydrol. Eng. 2013, 18, 99-107. [CrossRef]

2. Jim, C.Y.; Chen, W.Y. Ecosystem services and valuation of urban forests in China. Cities 2009, 26, 187-194. [CrossRef]

3. Jim, C.Y.; Chen, W.Y. Assessing the ecosystem service of air pollutant removal by urban trees in Guangzhou. J. Environ. Manag. 2008, 88, 665-676. [CrossRef] [PubMed]

4. Xu, Y.S.; Shen, S.L.; Yue, L.; Zhou, A.N. Design of Sponge City: Lessons learnt from an ancient drainage system in Ganzhou, China. J. Hydrol. 2018, 563, 900-908. [CrossRef]

5. Yu, C.; Hien, W.N. Thermal benefits of city parks. Energy Build. 2006, 38, 105-120. [CrossRef]

6. Ca, V.T.; Asaeda, T.; Abu, E.M. Reductions in air conditioning energy caused by a nearby park. Energy Build. 1998, 29, 83-92. [CrossRef]

7. Chandler, T.J. Urban Climatology and Its Relevance to Urban Design. In Technical Note No. 149; Secretariat of the World Meteorological Organisation: Geneva, Switzerland, 1976.

8. Di, S.; Li, Z.; Tang, R.; Pan, X.; Liu, H.; Niu, Y. Urban green space classification and water consumption analysis with remotesensing technology: A case study in Beijing, China. Int. J. Remote Sens. 2019, 40, 1909-1929. [CrossRef]

9. Litvak, E.; Mccarthy, H.R.; Pataki, D.E. A method for estimating transpiration of irrigated urban trees in California. Landsc. Urban Plan. 2017, 158, 48-61. [CrossRef]

10. Grimmond, C.S.B. The suburban energy balance: Methodological considerations and results for a mid-latitude west coast city under winter and spring conditions. Int. J. Climatol. 2010, 12, 481-497. [CrossRef]

11. Oke, T.R.; Zeuner, G.; Jauregui, E. The surface energy balance in Mexico City. Atmos. Environ. 1992, 26, 433-444. [CrossRef]

12. Spronken-Smith, R.A.; Oke, T.R.; Lowry, W.P. Advection and the surface energy balance across an irrigated urban park. Int. J. Climatol. 2000, 20, 1033-1047. [CrossRef]

13. Wang, C.; Yang, J.; Myint, S.W.; Wang, Z.; Tong, B. Empirical modeling and spatio-temporal patterns of urban evapotranspiration for the Phoenix metropolitan area, Arizona. GISci. Remote Sens. 2016, 53, 778-792. [CrossRef]

14. Tang, J.; Bolstad, P.V.; Ewers, B.E.; Desai, A.R.; Davis, K.J.; Carey, E.V. Sap flux-upscaled canopy transpiration, stomatal conductance, and water use efficiency in an old growth forest in the Great Lakes region of the United States. J. Geophys. Res.-Biogeosci. 2015, 111, G02009. [CrossRef]

15. Hernández-Santana, V.; David, T.S.; Martínez-Fernández, J. Environmental and plant-based controls of water use in a Mediterranean oak stand. For. Ecol. Manag. 2008, 255, 3707-3715. [CrossRef] 
16. Kim, S.J.; Kang, D.H.; Yu, H.; Kwon, B.H. Influence of Micrometeorological Factors for Actual Evapotranspiration in the Coastal Urban Area; AGU Fall Meeting: San Francisco, CA, USA, 2015.

17. Tognetti, R.; D'Andria, R.; Morelli, G.; Alvino, A. The effect of deficit irrigation on seasonal variations of plant water use in Olea europaea L. Plant Soil 2005, 273, 139-155. [CrossRef]

18. Lorenz, K.; Lal, R. Biogeochemical C and N cycles in urban soils. Environ. Int. 2009, 35, 1-8. [CrossRef]

19. Scalenghe, R.; Marsan, F.A. The anthropogenic sealing of soils in urban areas. Landsc. Urban Plan. 2009, 90, 1-10. [CrossRef]

20. Richard, G.; Cousin, I.; Sillon, J.F.; Bruand, A.; Guérif, J. Effect of compaction on the porosity of a silty soil: Influence on unsaturated hydraulic properties. Eur. J. Soil Sci. 2001, 52, 49-58. [CrossRef]

21. Horton, R.; Ankeny, M.D.; Allmaras, R.R. Effects of Compaction on Soil Hydraulic Properties. In Soil Compaction in Crop Production; Soane, B.D., van Ouwerkerk, C., Eds.; Elsevier: Amsterdam, The Netherlands, 1994; pp. 141-165.

22. Gregory, J.H.; Dukes, M.D.; Jones, P.H.; Miller, G.L. Effect of urban soil compaction on infiltration rate. J. Soil Water Conserv. 2006, 61, 117-124.

23. Chen, L.; Zhang, Z.; Li, Z.; Tang, J.; Caldwell, P.; Zhang, W. Biophysical control of whole tree transpiration under an urban environment in Northern China. J. Hydrol. 2011, 402, 388-400. [CrossRef]

24. Mitchell, P.J.; Veneklaas, E.; Lambers, H.; Burgess, S. Partitioning of evapotranspiration in a semi-arid eucalypt woodland in south-western Australia. Agric. For. Meteorol. 2009, 149, 25-37. [CrossRef]

25. Gazal, R.M.; Scott, R.L.; Goodrich, D.C.; Williams, D.G. Controls on transpiration in a semiarid riparian cottonwood forest. Agric. For. Meteorol. 2006, 137, 56-67. [CrossRef]

26. Voyde, E.; Fassman, E.; Simcock, R. Hydrology of an extensive living roof under sub-tropical climate conditions in Auckland, New Zealand. J. Hydrol. 2010, 394, 384-395. [CrossRef]

27. Tognetti, R.; Giovannelli, A.; Lavini, A.; Morelli, G.; Fragnito, F.; D’Andria, R. Assessing environmental controls over conductances through the soil-plant-atmosphere continuum in an experimental olive tree plantation of southern Italy. Agric. For. Meteorol. 2009, 149, 1229-1243. [CrossRef]

28. O'Grady, A.P.; Worledge, D.; Battaglia, M. Constraints on transpiration of Eucalyptus globulus in southern Tasmania, Australia. Agric. For. Meteorol. 2008, 148, 453-465. [CrossRef]

29. Johnson, T.D.; Belitz, K. A remote sensing approach for estimating the location and rate of urban irrigation in semi-arid climates. J. Hydrol. 2012, 414, 86-98. [CrossRef]

30. Gober, P.; Brazel, A.J.; Quay, R.; Myint, S.; Grossman-Clarke, S.; Miller, A.; Rossi, S. Using Watered Landscapes to Manipulate Urban Heat Island Effects: How Much Water Will It Take to Cool Phoenix? J. Am. Plan. Assoc. 2009, 76, 109-121. [CrossRef]

31. Kurc, S.A.; Small, E.E. Dynamics of evapotranspiration in semiarid grassland and shrubland ecosystems during the summer monsoon season, central New Mexico. Water Resour. Res. 2004, 40, W09305. [CrossRef]

32. Grimmond, C.S.B.; Oke, T.R. Evapotranspiration rates in urban areas. In Proceedings of the IUGG 99 Symposium HS5, Birmingham, UK, July 1999.

33. Decker, J.P.; Gaylor, W.G.; Cole, F.D. Measuring transpiration of undisturbed tamarisk shrubs. Plant Physiol. 1962, 37, 393-397. [CrossRef]

34. Oke, T.R. Advectively-assisted evapotranspiration from irrigated urban vegetation. Bound.-Layer Meteorol. 1979, 17, 167-173. [CrossRef]

35. Colby, B.G.; Jacobs, K.L. Lessons for Semiarid Regions Facing Growth and Competition for Water. In Arizona Water Policy; Routledge: London, UK, 2010; pp. 243-258.

36. Sabo, J.L.; Sinha, T.; Bowling, L.C.; Schoups, G.; Wallender, W.W.; Campana, M.E.; Cherkauer, K.A.; Fuller, P.L.; Graf, W.L.; Hopmans, J.W. Reclaiming freshwater sustainability in the Cadillac Desert. Proc. Natl. Acad. Sci. USA 2010, 107, 21263-21269. [CrossRef] [PubMed]

37. Evans, R.G.; Sadler, E.J. Methods and technologies to improve efficiency of water use. Water Resour. Res. 2008, 44, 767-768. [CrossRef]

38. Hilaire, R.S.; Arnold, M.A.; Wilkerson, D.C.; Devitt, D.A.; Hurd, B.H.; Lesikar, B.J.; Lohr, V.I.; Martin, C.A.; Mcdonald, G.V.; Morris, R.L.; et al. Efficient Water Use in Residential Urban Landscapes. Hortscience 2008, 43, 2081-2092. [CrossRef]

39. Litvak, E.; Pataki, D.E. Evapotranspiration of urban lawns in a semi-arid environment: An in situ evaluation of microclimatic conditions and watering recommendations. J. Arid Environ. 2016, 134, 87-96. [CrossRef]

40. Nouri, H.; Beecham, S.; Kazemi, F.; Hassanli, A.M. A review of ET measurement techniques for estimating the water requirements of urban landscape vegetation. Urban Water J. 2013, 10, 247-259. [CrossRef]

41. Sun, R.; Chen, L. How can urban water bodies be designed for climate adaptation? Landsc. Urban Plan. 2012, 105, 27-33. [CrossRef]

42. Snyder, R.L.; Pedras, C.; Montazar, A.; Henry, J.M.; Ackley, D. Advances in ET-based landscape irrigation management. Agric. Water Manag. 2015, 147, 187-197. [CrossRef]

43. Wang, H.; Ouyang, Z.; Chen, W.; Wang, X.; Hua, Z.; Ren, Y. Water, heat, and airborne pollutants effects on transpiration of urban trees. Environ. Pollut. 2011, 159, 2127-2137. [CrossRef]

44. Hagishima, A.; Narita, K.I.; Tanimoto, J. Field experiment on transpiration from isolated urban plants. Hydrol. Process. 2007, 21, 1217-1222. [CrossRef] 
45. Van Bavel, C.; Fritschen, L.J.; Reeves, W.E. Transpiration by sudangrass as an externally controlled process. Science 1963, 141, 269-270. [CrossRef]

46. Chen, S.; Chai, M.; Jia, Y.; Gao, Z.; Zhang, L.; Gu, M.; Lin, W.; Wang, L. In vitro selection of glyphosate-tolerant variants from long-term callus cultures of Zoysia matrella [L.] Merr. Plant Cell Tiss. Org. 2012, 111, 199-207. [CrossRef]

47. Shu, C.; Chai, M.; Jia, Y.; Gao, Z.; Gu, M. In vitro selection of salt tolerant variants following 60Co gamma irradiation of long-term callus cultures of Zoysia matrella [L.] Merr. Plant Cell Tiss. Org. 2011, 107, 493-500. [CrossRef]

48. Qiu, G.Y.; Yu, X.; Wen, H.; Yan, C. An advanced approach for measuring the transpiration rate of individual urban trees by the 3D three-temperature model and thermal infrared remote sensing. J. Hydrol. 2020, 587, 125034. [CrossRef]

49. Qiu, G.; Tan, S.; Yue, W.; Yu, X.; Yan, C. Characteristics of Evapotranspiration of Urban Lawns in a Sub-Tropical Megacity and Its Measurement by the 'Three Temperature Model + Infrared Remote Sensing' Method. Remote Sens.-Basel 2017, 9, 502. [CrossRef]

50. Bowen, I.S. The ratio of heat losses by conduction and by evaporation from any water surface. Phys. Rev. 1926, 27, 779-787. [CrossRef]

51. Perez, P.J.; Castellvi, F.; Ibanez, M.; Rosell, J.I. Assessment of reliability of Bowen ratio method for partitioning fluxes. Agric. For Meteorol. 1999, 97, 141-150. [CrossRef]

52. Granier, A. Evaluation of transpiration in a Douglas-fir stand by means of sap flow measurements. Tree Physiol. 1987, 3, 309-320. [CrossRef]

53. Lu, P.; Urban, L.; Zhao, P. Granier's thermal dissipation probe (TDP) method for measuring sap flow in trees: Theory and practice. J. Integr. Plant Biol. 2004, 46, 631-646.

54. Granier, A.; Gross, P. Mesure du flux de sève brute dans le tronc du Douglas par une nouvelle méthode thermique. Ann. Des Sci. For. 1987, 44, 1-14. [CrossRef]

55. Chen, L.; Zhang, Z.; Zha, T.; Mo, K.; Zhang, Y.; Fang, X. Soil water affects transpiration response to rainfall and vapor pressure deficit in poplar plantation. New For. 2014, 45, 235-250. [CrossRef]

56. Gartner, K.; Nadezhdina, N.; Englisch, M.; Čermak, J.; Leitgeb, E. Sap flow of birch and Norway spruce during the European heat and drought in summer 2003. For. Ecol. Manag. 2009, 258, 590-599. [CrossRef]

57. Snyder, K.A.; Richards, J.H.; Donovan, L.A. Night-time conductance in C3 and C4 species: Do plants lose water at night? J. Exp. Bot. 2003, 383, 861-865. [CrossRef] [PubMed]

58. Zeppel, M.; Lewis, J.D.; Chaszar, B.; Smith, R.A.; Medlyn, B.E.; Huxman, T.E.; Tissue, D.T. Nocturnal stomatal conductance responses to rising [CO2], temperature and drought. New Phytol. 2012, 193, 929-938. [CrossRef]

59. Daley, M.J.; Phillips, N.G. Interspecific variation in nighttime transpiration and stomatal conductance in a mixed New England deciduous forest. Tree Physiol. 2006, 26, 411-419. [CrossRef] [PubMed]

60. Fisher, J.B.; Baldocchi, D.D.; Misson, L.; Dawson, T.E.; Goldstein, A.H. What the towers don't see at night: Nocturnal sap flow in trees and shrubs at two AmeriFlux sites in California. Tree Physiol. 2007, 27, 597-610. [CrossRef] [PubMed]

61. Aguilos, M.; Stahl, C.; Burban, B.; Hérault, B.; Courtois, E.; Coste, S.; Wanger, F.; Ziegler, C.; Takagi, K.; Bonal, D. Interannual and Seasonal Variations in Ecosystem Transpiration and Water Use Efficiency in a Tropical Rainforest. Forests 2018, 10, 14. [CrossRef]

62. Zhang, Y.Y.; Qin, H.P.; Zhang, J.Y.; Hu, Y.C. An in-situ measurement method of evapotranspiration from typical LID facilities based on the three-temperature model. J. Hydrol. 2020, 588, 125105. [CrossRef]

63. Yu, X.; Yang, Y.; Tan, S.; Li, R.; Qin, H.; Qiu, G. Evapotranspiration and its cooling effect of urban green roof. Chin. J. Environ. Eng. 2017, 11, 5333-5340. [CrossRef]

64. Migliaccio, K.W.; Shoemaker, W.B. Estimation of urban subtropical bahiagrass (Paspalum notatum) evapotranspiration using crop coefficients and the eddy covariance method. Hydrol. Process. 2014, 28, 4487-4495. [CrossRef]

65. Litvak, E.; Bijoor, N.S.; Pataki, D.E. Adding trees to irrigated turfgrass lawns may be a water-saving measure in semi-arid environments. Ecohydrology 2014, 7, 1314-1330. [CrossRef]

66. Bastug, R.; Buyuktas, D. The effects of different irrigation levels applied in golf courses on some quality characteristics of turfgrass. Irrig. Sci. 2003, 22, 87-93. [CrossRef]

67. Amgain, N.R.; Harris, D.K.; Thapa, S.B.; Martin, D.L.; Wu, Y.; Moss, J.Q. Evapotranspiration Rates of Turf Bermudagrasses under Nonlimiting Soil Moisture Conditions in Oklahoma. Crop Sci. 2018, 58, 1409-1415. [CrossRef]

68. Peters, E.B.; Hiller, R.V.; Mc Fa Dden, J.P. Seasonal contributions of vegetation types to suburban evapotranspiration. J. Geophys. Res. Biogeosci. 2011, 116, G01003. [CrossRef]

69. Pataki, D.E.; McCarthy, H.R.; Litvak, E.; Pincetl, S. Transpiration of urban forests in the Los Angeles metropolitan area. Ecol. Appl. 2011, 21, 661-677. [CrossRef]

70. Asawa, T.; Kiyono, T.; Hoyano, A. Continuous measurement of whole-tree water balance for studying urban tree transpiration. Hydrol. Process. 2017, 31, 3056-3068. [CrossRef]

71. Lubczynski, M.W.; Gurwin, J. Integration of various data sources for transient groundwater modeling with spatio-temporally variable fluxes-Sardon study case, Spain. J. Hydrol. 2005, 306, 71-96. [CrossRef]

72. Jackson, R.B.; Jobbágy, E.G.; Avissar, R.; Roy, S.B.; Barrett, D.J.; Cook, C.W.; Farley, K.A.; Maitre, D.C.L.; McCarl, B.A.; Murray, B.C. Trading water for carbon with biological carbon sequestration. Science 2005, 310, 1944-1947. [CrossRef] [PubMed]

73. Huxman, T.E.; Wilcox, B.P.; Breshears, D.D.; Scott, R.L.; Snyder, K.A.; Small, E.E.; Hultine, K.; Pockman, W.T.; Jackson, R.B. Ecohydrological implications of woody plant encroachment. Ecology 2005, 86, 308-319. [CrossRef] 
74. Zhang, L.; Dawes, W.R.; Walker, G.R. Response of mean annual evapotranspiration to vegetation changes at catchment scale. Water Resour. Res. 2001, 37, 701-708. [CrossRef]

75. Yimam, Y.T.; Ochsner, T.E.; Kakani, V.G. Evapotranspiration partitioning and water use efficiency of switchgrass and biomass sorghum managed for biofuel. Agr. Water Manag. 2015, 155, 40-47. [CrossRef]

76. Guan, H.; Wilson, J.L. A hybrid dual-source model for potential evaporation and transpiration partitioning. J. Hydrol. 2009, 377, 405-416. [CrossRef]

77. Sutanto, S.J.; Wenninger, J.; Coenders-Gerrits, A.M.J.; Uhlenbrook, S. Partitioning of evaporation into transpiration, soil evaporation and interception: A comparison between isotope measurements and a HYDRUS-1D model. Hydrol. Earth Syst. Sci. 2012, 16, 2605-2616. [CrossRef]

78. Zhang, R.; Xu, X.; Liu, M.; Zhang, Y.; Xu, C.; Yi, R.; Luo, W. Comparing evapotranspiration characteristics and environmental controls for three agroforestry ecosystems in a subtropical humid karst area. J. Hydrol. 2018, 563, 1042-1050. [CrossRef]

79. Breuer, L.; Eckhardt, K.; Frede, H. Plant parameter values for models in temperate climates. Ecol. Model. 2003, 169, 237-293. [CrossRef]

80. Schenk, H.J.; Jackson, R.B. The global biogeography of roots. Ecol. Monogr. 2002, 72, 311-328. [CrossRef]

81. Zeng, X. Global Vegetation Root Distribution for Land Modeling. J. Hydrometeorol. 2001, 2, 525-530. [CrossRef]

82. Scharenbroch, B.C.; Carter, D.; Bialecki, M.; Fahey, R.; Scheberl, L.; Catania, M.; Roman, L.A.; Bassuk, N.; Harper, R.W.; Werner, L.; et al. A rapid urban site index for assessing the quality of street tree planting sites. Urban For. Urban Green. 2017, 27, 279-286. [CrossRef]

83. Sanders, J.R.; Grabosky, J.C. 20 years later: Does reduced soil area change overall tree growth? Urban For. Urban Green. 2014, 13, 295-303. [CrossRef]

84. Day, S.D.; Bassuk, N.L. A review of the effects of soil compaction and amelioration techniques on landscape trees. J. Arboric. 1994, 20,9-17.

85. Monteith, J.I.L. Evaporation and Environment. Symp. Soc. Exp. Biol. 1965, 19, 205-234. [PubMed]

86. Penman, H.L. Natural Evaporation from Open Water, Bare Soil and Grass. Proc. R. Soc. Lond. 1948, 193, 120-145. [CrossRef]

87. Aranda, I.; Forner, A.; Cuesta, B.; Valladares, F. Species-specific water use by forest tree species: From the tree to the stand. Agric. Water Manag. 2012, 114, 67-77. [CrossRef]

88. Jarvis, P.G.; Mcnaughton, K.G. Stomatal control of transpiration: Scaling up from leaf to region. Adv. Ecol. Res. 1986, 15, 1-49. [CrossRef]

89. Collatz, G.J. Physiological and environmental regulation of stomatal conductance, photosynthesis and transpiration: A model that includes a laminar boundary layer. Agric. For. Meteorol. 1991, 54, 107-136. [CrossRef]

90. Wen, D.Z. Ecophysiological Responses and Sensitivity of 39 Woody Species Exposed to Air Pollution. J. Trop. Subtrop. Bot. 2003, 11, 341-347.

91. Li, G. The Photosynthesis and Water Use Efficiency of Eight Garden Tree Species. For. Res. 2002, 15, 291-296. [CrossRef]

92. Konarska, J.; Holmer, B.; Lindberg, F.; Thorsson, S. Influence of vegetation and building geometry on the spatial variations of air temperature and cooling rates in a high latitude city. Int. J. Climatol. 2016, 36, 2379-2395. [CrossRef]

93. Nielsen, C.N.; Bühler, O.; Kristoffersen, P. Soil Water Dynamics and Growth of Street and Park Trees. Arboric. Urban For. 2007, 33, 231-245.

94. Bühler, O.; Nielsen, C.N.; Kristoffersen, P. Growth and phenology of established street trees in response to different irrigation regimes. Arboric. Urban For. 2006, 32, 3-9. 